\title{
Power Loss Reduction and Voltage Profile Improvement in Electrical Power Distribution Networks Using Static Var Compensators
}

\author{
Bankole Adebanji ${ }^{\mathrm{a},}{ }^{*}$, Wale Akinyele ${ }^{\mathrm{a}}$, Juliet Femi-Jemilohun ${ }^{\mathrm{a}}$, Chukwuemeka Okafor ${ }^{\mathrm{a}}$, Isiaka Ismail ${ }^{\mathrm{a}}$ \\ ${ }^{a}$ Electrical and Electronic Engineering, Ekiti State University, Ado-Ekiti, Nigeria \\ Corresponding author: *bankole.adebanji@eksu.edu.ng
}

\begin{abstract}
Rising demand for electrical power due to the global technological advancement has brought so many challenges such as instability of voltage, huge power loss, and unstable power factor on the distribution network. This work applied Static Var Compensator (SVC) to the power distribution network of Ado-Ekiti, Nigeria, to study its effect on active power loss reduction and voltage profile improvement of the network. The bus voltage, power, and the current flowing through the selected feeders were measured and recorded accordingly for analysis. Test network parameters like route length, transformer parameters, and maximum power flow were obtained from Benin Electricity Distribution Company, Ado-Ekiti, Nigeria. The distribution network was then modeled and simulated with and without SVC in NEPLAN software environment. The simulation results of the power flow and voltage stability analyses of the network without SVCs showed that some distribution lines were overloaded and that the network parameters were not within the statutory tolerable limits of 0.95 p.u. and 1.05 p.u. nominal voltage. There was $9.73 \%$ reduction in the active power loss when SVCs were incorporated into the test network. The voltage stability curve showed an increase in distribution network capacity from an initial steady-state of $150 \%$ to $263 \%$ of the total active load when the SVCs were incorporated. Hence, the need to normalize the network by applying SVCs to all the buses with very low voltages. This work will assist the power distribution supply companies in making some informed decisions in reducing power losses on their networks.
\end{abstract}

Keywords - Active power loss; distribution network; NEPLAN; static var compensator; voltage fluctuation.

\section{INTRODUCTION}

Electrical power is an inherent commodity because it drives the economy and sustains the developmental growth of any country. There is, therefore, an interrelation between the standard of living and the available power delivered in a country [1], [2]. Electricity distribution systems deal with collecting activities and equipment to ensure that power is effectively delivered from the transmission station to the final electricity end-users [3], [4].

In electrical power distribution networks, network power loss and voltage stability are the most important factors showing the quality of power supplied to the electricity endusers [5]. Electrical and electronic devices are designed to work on a specified voltage, frequency, and current rating. Variation from the specified values discomposes weighty menaces to the whole power networks [6].

The power distribution network in Nigeria is peculiar with heavy power losses and voltage drop, which is a major cause of very poor quality of electrical power arriving at electricity end-users [7]. Electrical power network suffers largely from voltage instability especially due to excessive consumption or injection of reactive power by the system elements and the consumers' load. The network's voltage goes high if there is the excessive injection of reactive power by the network elements or the electricity end-user's loads but goes low if the reactive power being consumed by the network elements or electrical load is excessive.

As a result, the power system's reactive power needs to be constantly regulated through adequate reactive power compensation [5]. In this case, the old-fashioned techniques employed include reconfiguring network structure, synchronous generator, changing the voltage by transformer tap to regulate the power flow in the grid, and series compensation capacitors [8]. With these techniques, the desired objectives were not efficiently realized, with wear and tear in mechanical devices and slow response being the main challenges [9].

The existing distribution line basic facility is not capable of supporting the increasing load demand. These result in 
voltage drop profile, increased network losses, poor network efficiency, instability, and disturbance [10]. Under the pressured situation, one of the efficient ways to save the network from voltage collapse is to lessen the reactive power load or add additional reactive power sources by introducing reactive power sources such as Static Var Compensator (SVC) [11]. The SVC has a positive contact on improving the network voltage profile, improving the power factor, voltage stability, and minimizing power loss. According to the Institute of Electrical and Electronics Engineers (IEEE), the allowable voltage standard is between 0.95 p.u. and 1.05 p.u. [12]. A suitable electric power network must have a voltage that does not exceed the tolerance limit and have very small power losses. The voltage drop affects the power losses. Power losses are inevitable but can be minimized by enhancing the voltage profile.

Extensive research works were carried out recently, leading to the discovery of Flexible AC transmission system (FACTS) devices that have been chiefly employed to solve different power system steady-state control problems such as power flow control, voltage regulation, and transferability improvement near-instantaneous response [13]. Many studies [3], [19] have shown that most of the electrical power quality issues directly result from deviations in the network's reactive power. FACTS technology that shows the rapid response to network changes was used by Beagon et al. [14] to enhance power network efficiency without changing the network structure. Singh and Agrawal [10] worked on improving voltage profiles by reducing the active and reactive power losses using optimal load flow methodology in MATLAB environment. This was done by the incorporation of SVC in the power system network. The effectiveness of the methodology was tested on IEEE-9 and IEEE-30 bus systems.

Jumat et al. [11] modeled and simulated SVC using MATLAB/Simulink software to improve the voltage profile of a transmission system. The proposed methodology was validated using four case study areas. The simulation results showed a positive effect on the system's voltage. An optimal location and number of Unified Flow Controller (UPFC) devices to improve voltage profile and reduce the electrical system losses were carried out by Hocine and Djamel [13]. The work proposed a method by which the optimal number, size, and locations of UPFC enhance reduced system losses and enhance voltage profile. The methodology was applied to a standard IEEE 14 test system. Suliman [20] worked on voltage profile improvement on the distribution network. The work presented a fuzzy controller based on Static Synchronous Compensator (STATCOM). The stability margin was increased by about $20 \%$.

Most of the research reviewed so far used different loss minimization techniques that get more complicated as the number of buses increases. The methods adopted also depend on the specific case study areas. It can be observed that most of the work done was on voltage improvement and loss reduction on transmission networks. However, this paper seeks to study the effect of SVC in reducing the network's active power loss and improving voltage profile through adequate reactive power compensation using an electrical power distribution network, Ado-Ekiti, Nigeria, as a test system.

\section{A. Power Flow Analysis}

Load flow analysis is a suitable tool to ascertain the complex electrical power system [15]. It is used to evaluate reactive and active power and voltage and electric current passing through the power line at different buses in a network. It is also helpful for effective planning and monitoring of network's behavior and evaluating the best size and suitable location of shunt devices to improve the power factor, voltage level and minimize the network power loss.

\section{B. The Flexible AC Transmission System (FACTS) Controllers}

FACTS controllers are used to improving the controllability and raise the electrical power transferability of a distribution network. There are several types of FACTS controller configuration, such as Thyristor-controlled phase shifter (TCPS), Static Synchronous Series Compensator (SSSC), Thyristor-controlled series compensator (TCSC), Static Synchronous Compensator (STATCOM), and Static Var Compensator (SVC) [16]. The FACTS controller considered in this work is SVC because it is reliable and not expensive. A Static Var Compensator (SVC) is a parallel combination of a controlled reactor and switched capacitor. It is used to supply rapid operating reactive power in the electrical power network. It combined both capacitors and reactors for rapid regulation of electrical power network variables [17]. They are applied in electrical power networks for various purposes, the principal of which is fast control of bus voltage at weak buses in an electrical power network. Static Var Compensator-TCR-TSC is shown in Figure 1.

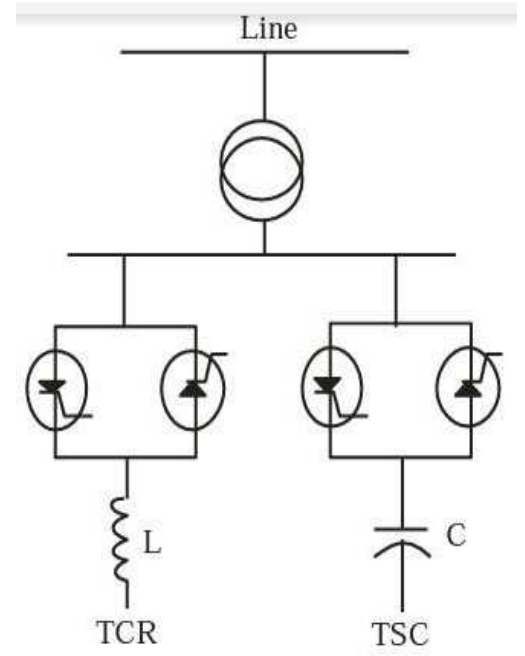

Fig. 1 Static var compensator-TCR- TSC [15]

Majorly, SVC comprises a fast thyristor switch regulating both shunt capacitor and inductor [17], [21]. SVC is connected as thyristor-controlled-reactor and thyristorswitched capacitor (TCR-TSC). The term "Static" is used to show that SVC has no rotating main components. The thyristor switch assembly regulates the voltage across the inductor and, therefore, the electric current flowing through the inductor. Thus, the reactive power absorbed by the inductor can be regulated [19], [20], [23]. 


\section{MATERIALS AND METHOdS}

The test distribution network considered for this study is the $33 / 11 \mathrm{kV}$ injection substation, Ado-Ekiti, Nigeria. The single line diagram of the substation network is as shown in Figure 2. The substation consists of two power transformers, each having capacity of 15 MVA. There are two outgoing feeders connected to each of the power transformers, the incoming voltage level is $33 \mathrm{kV}$, and the distribution voltage level is $11 \mathrm{kV}$. The electrical loads connected to the output terminals of the distribution transformer receive a voltage of $0.415 \mathrm{kV}$. For the simplicity of the network analysis, the total distribution transformers on each feeder are shown by its equivalent single distribution transformer.

The two selected feeders (Adebayo and Okesa) were considered for the analysis.

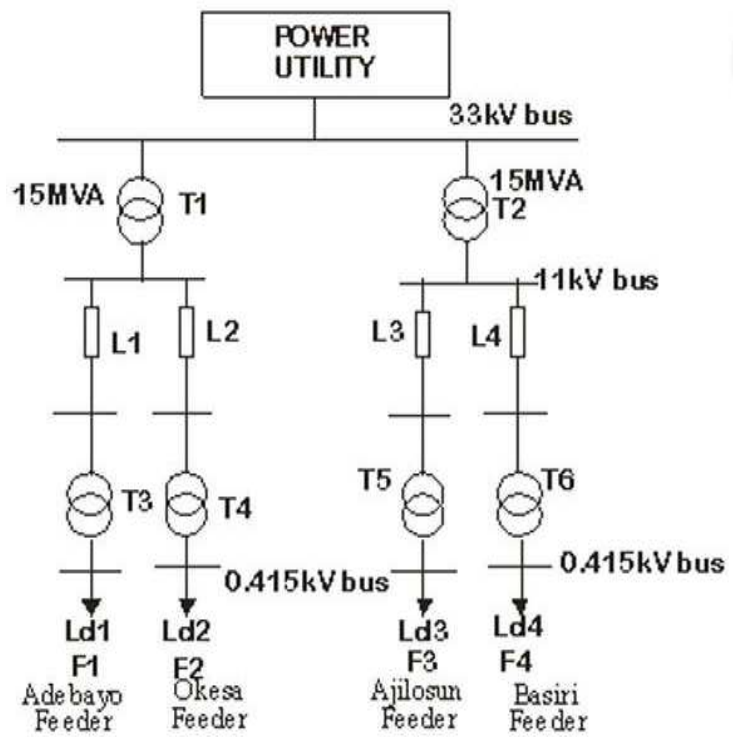

Fig. 2 Single line diagram of the $33 / 11 \mathrm{kV}$ injection substation, AdoEkiti

The selected network data such as total route length of the distribution feeders, distribution transformer parameters, active and reactive power sent, bus voltage, and system power factor needed for the load flow analysis were obtained from Benin Electricity Distribution Company's records Nigeria (BEDC). The relevant data for the $33 / 11 \mathrm{kV}$ Injection substation is as in Table 1, Table 2, and Table 3. The load current at each load point was measured and recorded accordingly (Appendices A and B) at peak load conditions. This was used in estimating the total load demand on each of the distribution transformers.

TABLE I

RELEVANT RECORDED DATA OF THE 33/11 KV POWER NETWORK, ADO-EKITI

\begin{tabular}{llllll}
\hline $\begin{array}{l}11 \mathrm{kV} \\
\text { Feeders }\end{array}$ & $\begin{array}{l}\text { Active } \\
\text { power } \\
\text { sent } \\
\text { (MW) }\end{array}$ & $\begin{array}{l}\text { Reactive } \\
\text { power } \\
\text { sent } \\
\text { (MVAR) }\end{array}$ & $\begin{array}{l}\text { Bus } \\
\text { Voltage } \\
\text { (kV) }\end{array}$ & $\begin{array}{l}\text { Power } \\
\text { Factor } \\
\text { (P.F) }\end{array}$ & $\begin{array}{l}\text { Current } \\
\text { (A) at } \\
\text { Feeders }\end{array}$ \\
\hline Adebayo & 6.30 & 2.29 & 110.8 & 0.94 & 360 \\
Okesa & 5.10 & 2.01 & 110.9 & 0.93 & 288 \\
Basiri & 6.02 & 2.07 & 111.0 & 0.95 & 346 \\
Ajilosun & 5.85 & 2.00 & 111.0 & 0.95 & 334 \\
\hline
\end{tabular}

TABLE II

DISTRIBUTION LINE PARAMETERS

\begin{tabular}{ccc}
\hline Parameter & Adebayo Feeder & Okesa Feeder \\
\hline Resistance per km in ohm & 0.28 & 0.28 \\
Reactance per km in ohm & 0.32 & 0.32 \\
Route length in km & 28.7 & 13.8 \\
\hline
\end{tabular}

TABLE III

TRANSFORMERS ON EACH FEEDER

\begin{tabular}{cccccc}
\hline $\begin{array}{c}11 \mathbf{k V} \\
\text { Feeders }\end{array}$ & $\begin{array}{r}\mathbf{5 0 0} \\
\mathbf{k V A}\end{array}$ & $\begin{array}{r}\mathbf{3 1 5} \\
\mathbf{k V A}\end{array}$ & $\begin{array}{r}\mathbf{3 0 0} \\
\mathbf{k V A}\end{array}$ & $\begin{array}{r}\mathbf{2 0 0} \\
\mathbf{k V A}\end{array}$ & $\begin{array}{c}\text { TOTA } \\
\text { L }\end{array}$ \\
\hline Adebayo & 13 & 1 & 19 & 2 & 35 \\
Okesa & 9 & 1 & 14 & 1 & 25 \\
\hline
\end{tabular}

\section{A. Mathematical Model of Distribution Network}

The network can be represented by an equivalent singleline diagram in a balanced distribution system, as shown in Figure 3. The line shunt capacitances at distribution voltage levels are very small and, therefore, can be neglected [21], [23]. The mathematical model of the radial distribution network is derived from Figure 3. Equation 1 and Equation 2 were derived as expressed in Figure 3.

$$
\begin{aligned}
& I(j j)=\frac{V\left({ }_{m 1}\right)<\delta\left({ }_{m 1}\right)-V\left({ }_{m 2}\right)<\delta\left(_{(m 2}\right)}{Z(j j)} \\
& P\left({ }_{m 2}\right)-j Q\left(_{m 2}\right)=V *\left(_{m 2}\right) x I(j j)
\end{aligned}
$$

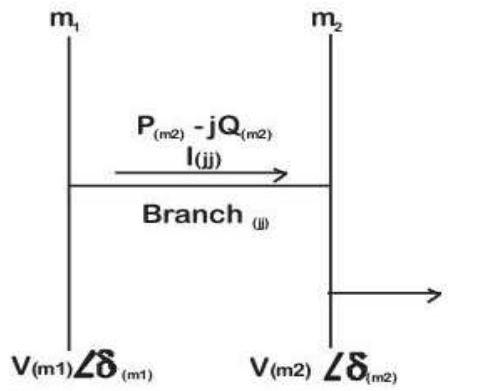

Fig. 3 Mathematical model of distribution network [21]

where,

$\mathrm{m}_{1}$ and $\mathrm{m}_{2}$ are the sending and receiving end buses respectively,

$\mathrm{P}\left(\mathrm{m}_{2}\right)$ is the addition of active power loads of all the buses beyond bus $m_{2}$ plus active power load of the bus $m_{2}$ itself plus the addition of the active power losses of all the branches beyond bus $\mathrm{m}_{2}$,

$\mathrm{Q}\left(\mathrm{m}_{2}\right)$ is the addition of reactive power loads of all the buses beyond bus $\mathrm{m}_{2}$ plus reactive power load of the bus $\mathrm{m}_{2}$ itself plus the addition of the reactive power losses of all the branches beyond bus $\mathrm{m}_{2}$,

$\mathrm{I}(\mathrm{ji})$ is the current flowing through the branch $\mathrm{jj}$,

$\mathrm{V}(\mathrm{i})$ is the magnitude of the voltage of the $\mathrm{i}^{\text {th }}$ node, $\delta\left({ }_{m 1}\right)$ is the voltage angle of node $m_{1}$,

$\delta\left({ }_{m 2}\right)$ is the voltage angle of node $m_{2}$,

$\mathrm{R}(\mathrm{jj})$ is the resistance of the branch $\mathrm{jj}$,

$\mathrm{X}(\mathrm{jj})$ is the reactance of the branch $\mathrm{jj}$.

From Equation 1 and Equation 2, we get Equation 3

$$
\mathrm{V}(\mathrm{m} 2)=\sqrt{B(j j)-A(j j)}
$$

where, 


$$
\begin{gathered}
\mathrm{A}(\mathrm{jj})=\mathrm{P}(\mathrm{m} 2) \times \mathrm{R}(\mathrm{jj})+\mathrm{Q}(\mathrm{m} 2) \times \mathrm{X}(\mathrm{jj})-0.5 \mathrm{x}[\mathrm{V}(\mathrm{m} 1)] 2 \\
\mathrm{~B}(\mathrm{jj})=\sqrt{A^{2}\left({ }_{j j}\right)-\left[Z^{2}\left({ }_{j j}\right) x\left(P^{2}\left(_{m 2}\right)+Q^{2}\left(_{m 2}\right)\right]\right.}
\end{gathered}
$$

The real and reactive power loss of branch $\mathrm{jj}$ is given by Eq.6 and Eq.7

$$
\begin{aligned}
L P\left({ }_{j j}\right) & =\frac{R(j j) x\left[P^{2}(m 2)+Q^{2}\left(m_{2}\right)\right]}{V\left(m_{2}\right)^{2}} \\
L Q(j j & =\frac{X(j j) x\left[P^{2}\left(m_{2}\right)+Q^{2}(m 2)\right]}{V(m 2)^{2}}
\end{aligned}
$$

Calculations were performed successively till the convergence standard is obtained [21], [22], [24], [25].

\section{B. Research Approach}

This detailed modeling and simulation of the $11 \mathrm{kV}$ distribution network, Ado-Ekiti by supplying the data obtained into advanced computer aided analysis tool (NEPLAN software). The systematic flowchart for the research is as shown in Figure 4.

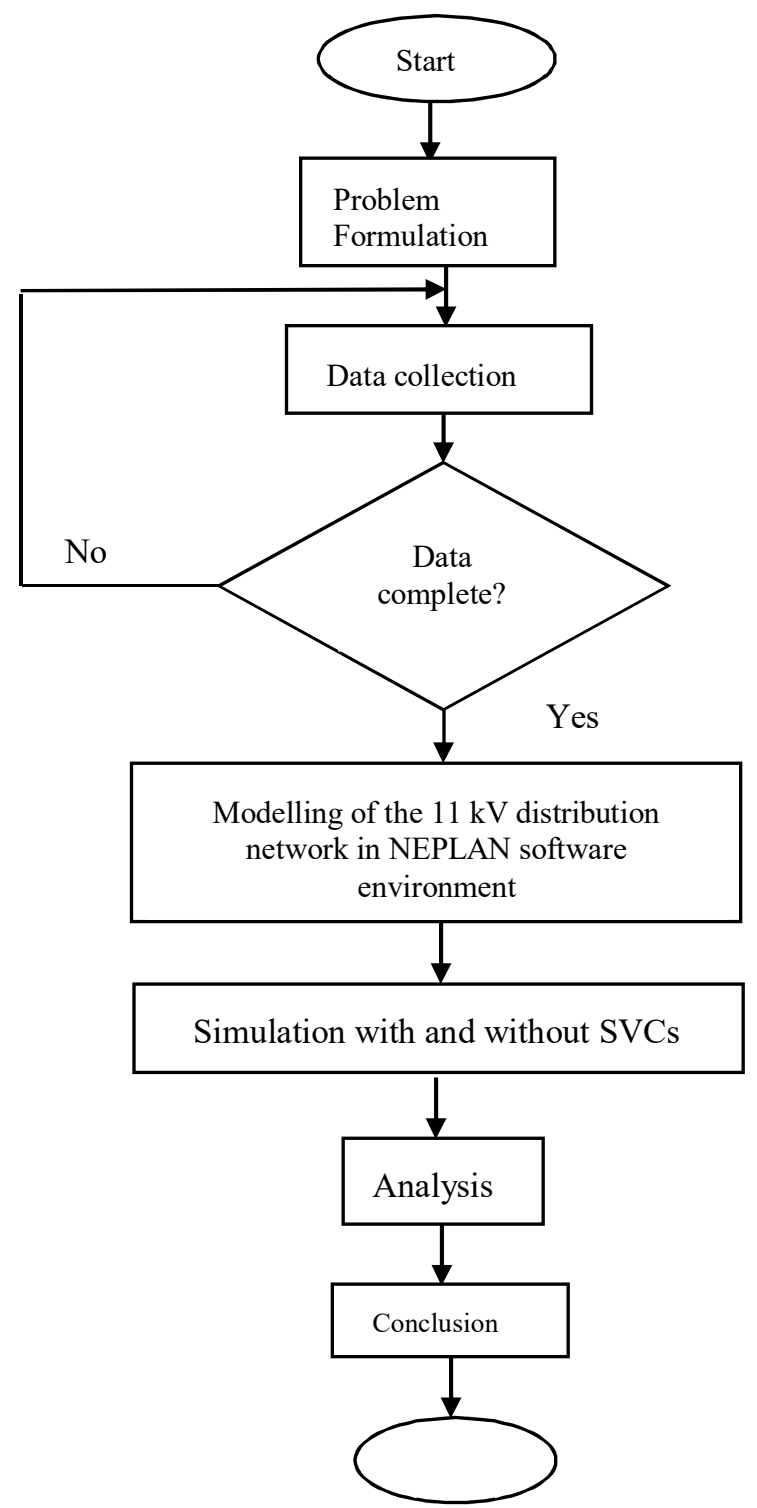

Fig. 4 Systematic flowchart for the research methodology
The distribution network (Figure 2) was considered for load flow analysis based on the following assumptions.

- The incoming $33 \mathrm{kV}$ bus is considered as slack or reference assumptions.

- Length of $0.415 \mathrm{kV}$ low tension service line is neglected.

- All loads are assumed to be static.

- The analysis is made for the steady state condition.

- Tolerance limits 0.95 p.u to 1.05 p.u of normal voltage

The distribution network was then modeled with and without FACTS controller (SVC) using NEPLAN software. These were subsequently discussed in the following subsections.

1) Simulation without FACTS controllers (SVCs): Simulation without SVC was carried out. The distribution network (Figure 2) was modeled and simulated in NEPLAN environment. The selected network data was used as inputs to create a virtual diagrammatic simulator, as shown in Figure 5. The simulation is carried out in stages as follows:

- Step 1: Selection of components. Power system components like transformers, distributions line, buses, loads are selected from the NEPLAN library.

- Step 2: Development of the network: Single line diagram was developed using different elements in the NAPLAN library.

- Step 3: Mode for analysis: The Newton Raphson Technique was employed for the network modeling and simulation due to its remarkable convergence.

- Step 4: Simulation output: Power flow was carried out, and results were obtained.

2) Simulation with FACTS Controllers (SVCS): Simulation with controllers is carried out using the steps explained in subsection 1 in the previous section. SVCs are applied to weak buses, and the computer simulation is done on the selected network in order to obtain results based on the input data.

\section{RESULTS AND Discussions}

The results of the simulation as carried out in the previous section are presented and discussed in this section.

\section{A. Simulation Results with and without FACTs Controllers (SVCs)}

The power flow analysis results of the $11 \mathrm{kV}$-bus voltages (Adebayo feeder) with and without SVCs are shown in Figure 6 , while the load bus voltage (Adebayo feeder) with and without SVCs is as in Table 4. The power flow analysis results of the $11 \mathrm{kV}$-bus voltages (Okesa feeder) with and without SVCs are shown in Figure 7, while the load bus voltage (Okesa feeder) with and without SVCs is as in Table 5. Figure 8 shows the voltage stability curve obtained under the initial steady-state operation without the SVCs, while the voltage stability curve obtained after normalizing (with SVCs) the network operating parameters are shown in Figure 9. The total active power loss with and without SVCs is as shown in Figure 10. 


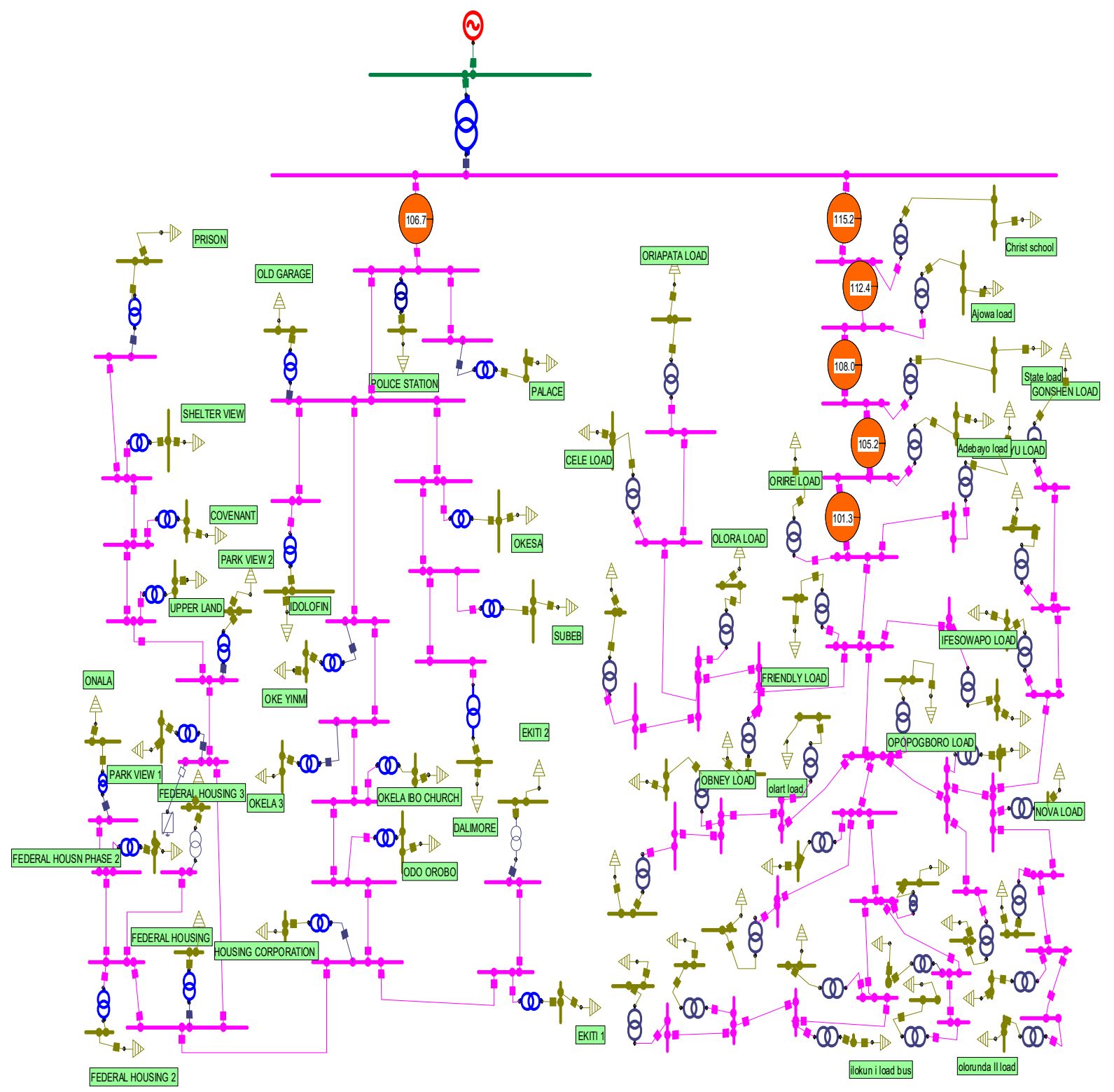

Fig. 5 The modelled-Ado-Ekiti 33/11 kV power network in NEPLAN without SVCs

Voltage Profile

- SIMULATION RESULTS VOLTAGE (kV) WITHOUT SVC

- SIMULATION RESULTS VOLTAGE (KV) WITH SVC

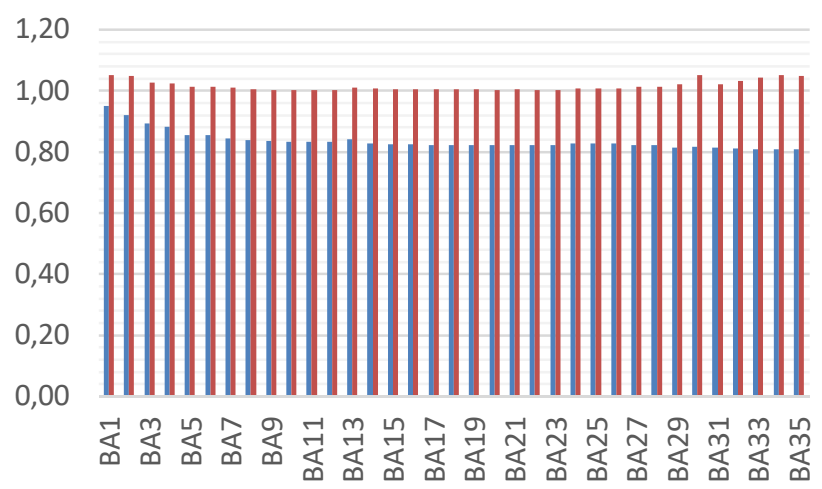

Fig. 6 Voltage profile of $11 \mathrm{kV}$ (Adebayo) feeder with and without SVCs

\section{Voltage Profile}

- SIMULATION RESULTS VOLTAGE (kV) WITHOUT SVC

- SIMULATION RESULTS VOLTAGE (kV) WITH SVC

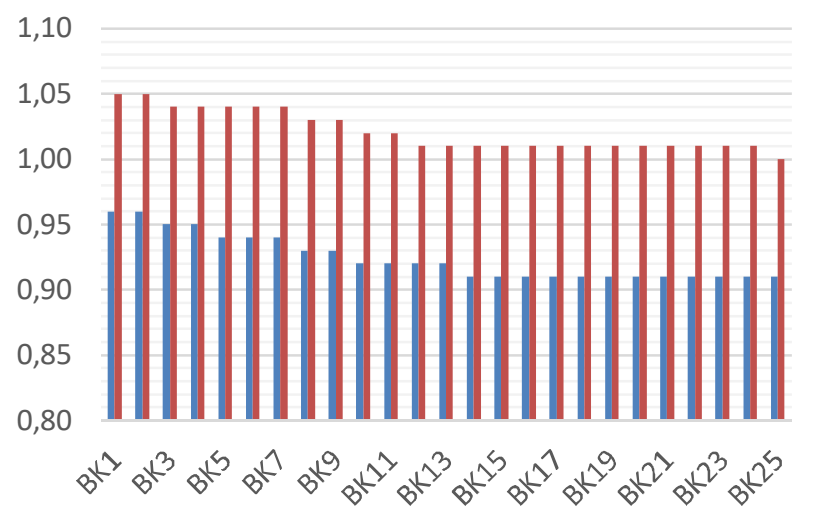

Fig. 7 Voltage profile of $11 \mathrm{kV}$ (Okesa) feeder with and without SVCs 
TABLE IV

LOAD BUS VOLTAGES (ADEBAYO FEEDER) WITHOUT AND WITH SVCS

\begin{tabular}{|c|c|c|c|c|c|}
\hline \multirow{3}{*}{$\begin{array}{l}\text { Bus } \\
\text { No }\end{array}$} & \multirow{3}{*}{ Load Bus Name } & \multicolumn{4}{|c|}{ Simulation Results Voltage (kV) } \\
\hline & & \multicolumn{2}{|c|}{ Without SVC } & \multicolumn{2}{|c|}{ With SVC } \\
\hline & & $(\mathrm{kV})$ & $V($ p.u. $)$ & $(\mathrm{kV})$ & V(p.u.) \\
\hline 1 & Christ School & 0.388 & 0.935 & 0.431 & 1.039 \\
\hline 2 & Ajowa & 0.377 & 0.908 & 0.426 & 1.027 \\
\hline 3 & State & 0.367 & 0.884 & 0.423 & 1.019 \\
\hline 4 & Adebayo & 0.361 & 0.87 & 0.42 & 1.012 \\
\hline 5 & Orire & 0.35 & 0.843 & 0.416 & 1.002 \\
\hline 6 & Jimoh Aliyu & 0.35 & 0.843 & 0.417 & 1.005 \\
\hline 7 & Friendly & 0.343 & 0.827 & 0.414 & 0.998 \\
\hline 8 & Obey & 0.341 & 0.822 & 0.412 & 0.993 \\
\hline 9 & Olora & 0.336 & 0.81 & 0.408 & 0.983 \\
\hline 10 & Ifelore & 0.341 & 0.822 & 0.412 & 0.993 \\
\hline 11 & Cele & 0.34 & 0.819 & 0.411 & 0.99 \\
\hline 12 & Oriapata & 0.34 & 0.819 & 0.411 & 0.99 \\
\hline 13 & Iyalaje & 0.345 & 0.831 & 0.415 & 1 \\
\hline 14 & Opopogbooro & 0.338 & 0.814 & 0.414 & 0.998 \\
\hline 15 & Abaibira 1 & 0.338 & 0.814 & 0.414 & 0.998 \\
\hline 16 & Abaibira 1 & 0.339 & 0.817 & 0.414 & 0.998 \\
\hline 17 & Nova & 0.335 & 0.807 & 0.411 & 0.99 \\
\hline 18 & Ifesowapo & 0.336 & 0.81 & 0.412 & 0.993 \\
\hline 19 & Aponwe & 0.337 & 0.812 & 0.413 & 0.995 \\
\hline 20 & Goshen & 0.336 & 0.81 & 0.413 & 0.995 \\
\hline 21 & Olorunsogo & 0.329 & 0.793 & 0.407 & 0.981 \\
\hline 22 & Olorunda 1 & 0.334 & 0.805 & 0.411 & 0.99 \\
\hline 23 & Olorunda 2 & 0.335 & 0.807 & 0.412 & 0.993 \\
\hline 24 & Olart & 0.338 & 0.814 & 0.414 & 0.998 \\
\hline 25 & Balemo & 0.336 & 0.81 & 0.413 & 0.995 \\
\hline 26 & Bolorunduro & 0.338 & 0.814 & 0.414 & 0.998 \\
\hline 27 & Adehun & 0.336 & 0.81 & 0.417 & 1.005 \\
\hline 28 & Ileileri & 0.33 & 0.795 & 0.412 & 0.993 \\
\hline 29 & Peace 1 & 0.334 & 0.805 & 0.421 & 1.014 \\
\hline 30 & Peace 2 & 0.335 & 0.807 & 0.421 & 1.014 \\
\hline 31 & Ore Ofe & 0.332 & 0.8 & 0.42 & 1.012 \\
\hline 32 & Irewumi & 0.333 & 0.802 & 0.425 & 1.024 \\
\hline 33 & Ilokun 1 & 0.295 & 0.711 & 0.407 & 0.981 \\
\hline 34 & Ilokun 2 & 0.331 & 0.798 & 0.43 & 1.036 \\
\hline 35 & Isegere & 0.35 & 0.795 & 0.432 & 1.041 \\
\hline
\end{tabular}

TABLE V

LOAD BUS VOLTAGE (OKESA FEEDER) WITHOUT AND WITH SVCS

\begin{tabular}{|c|c|c|c|c|c|}
\hline \multirow{3}{*}{$\begin{array}{l}\text { Bus } \\
\text { No }\end{array}$} & \multirow{3}{*}{ Load Bus Name } & \multicolumn{4}{|c|}{ Simulation Results Voltage $(\mathrm{kV})$} \\
\hline & & \multicolumn{2}{|c|}{ Without SVC } & \multicolumn{2}{|c|}{ With SVC } \\
\hline & & $(\mathrm{kV})$ & $\mathrm{V}($ p.u. $)$ & $(\mathrm{kV})$ & V(p.u.) \\
\hline 1 & Police Station & 0.392 & 0.94 & 0.43 & 1.04 \\
\hline 2 & Palace & 0.389 & 0.94 & 0.427 & 1.03 \\
\hline 3 & Old Garage & 0.386 & 0.93 & 0.425 & 1.02 \\
\hline 4 & Idolofin & 0.382 & 0.92 & 0.421 & 1.01 \\
\hline 5 & Oke-Ese & 0.389 & 0.94 & 0.427 & 1.03 \\
\hline 6 & SUBEB & 0.386 & 0.93 & 0.425 & 1.02 \\
\hline 7 & Dallimore & 0.384 & 0.93 & 0.423 & 1.02 \\
\hline 8 & Okeyinmi & 0.384 & 0.93 & 0.423 & 1.02 \\
\hline 9 & Okeila 3 (Rosebud) & 0.381 & 0.92 & 0.42 & 1.01 \\
\hline 10 & Oke ila (Ibo Church) & 0.379 & 0.91 & 0.419 & 1.01 \\
\hline 11 & Odo Orobo & 0.375 & 0.90 & 0.415 & 1.00 \\
\hline 12 & $\begin{array}{l}\text { Housing } \\
\text { Corporation }\end{array}$ & 0.375 & 0.90 & 0.415 & 1.00 \\
\hline 13 & Ekiti 1 & 0.378 & 0.91 & 0.417 & 1.00 \\
\hline 14 & Ekiti 2 & 0.38 & 0.92 & 0.419 & 1.01 \\
\hline 15 & Fed. Housing 1 & 0.37 & 0.89 & 0.41 & 0.99 \\
\hline 16 & Fed. Housing 2 & 0.37 & 0.89 & 0.41 & 0.99 \\
\hline 17 & Fed housing 3 & 0.374 & 0.90 & 0.414 & 1.00 \\
\hline 18 & $\begin{array}{l}\text { Fed Housing Phase } \\
2\end{array}$ & 0.374 & 0.90 & 0.414 & 1.00 \\
\hline 19 & Onala & 0.372 & 0.90 & 0.412 & 0.99 \\
\hline 20 & Park view 1 & 0.371 & 0.89 & 0.411 & 0.99 \\
\hline 21 & Park View 2 & 0.372 & 0.90 & 0.412 & 0.99 \\
\hline 22 & Upper Load & 0.373 & 0.90 & 0.413 & 1.00 \\
\hline 23 & Covenant & 0.37 & 0.89 & 0.41 & 0.99 \\
\hline 24 & Shelter View & 0.374 & 0.90 & 0.415 & 1.00 \\
\hline 25 & Prison & 0.375 & 0.90 & 0.415 & 1.00 \\
\hline
\end{tabular}

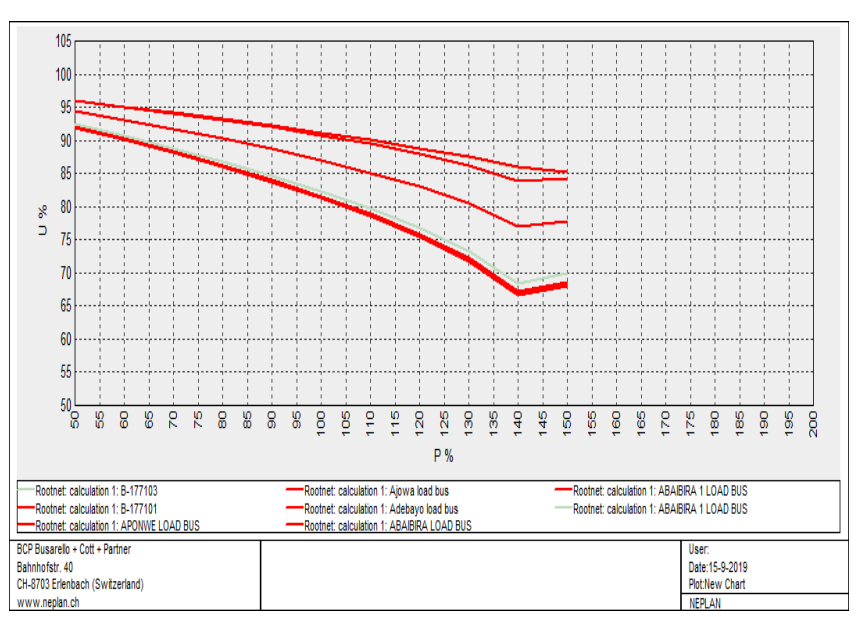

Fig. 8 Voltage stability curve under initial steady state operation withou SVCs 


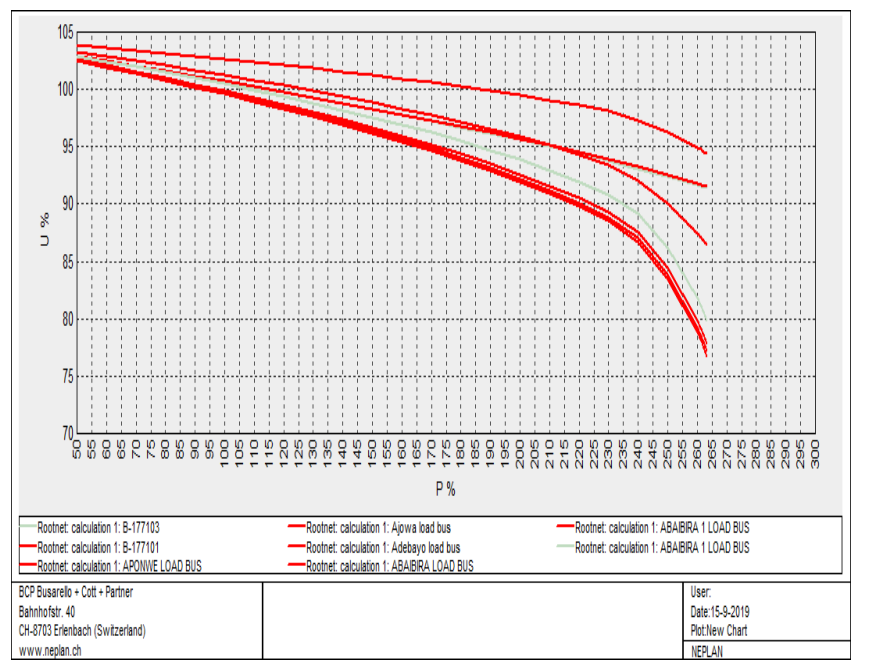

Fig. 9 Voltage stability curve under normal steady-state operation with SVCs

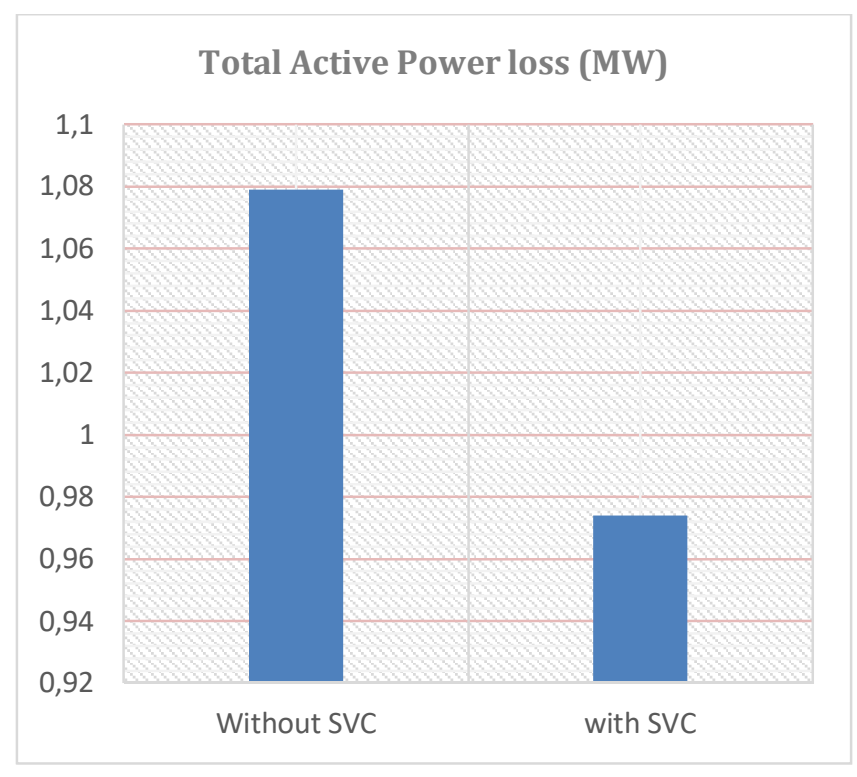

Fig. 10 Total active power loss with and without SVCs

\section{B. Discussion}

The simulation results with and without SVCs were discussed in the following subsections.

1) Simulation without FACTs controllers (SVCs): The results show that the network parameters are not within the statutory tolerable limits of 0.95 p.u. to 1.05 p.u. of the nominal voltage when the networks were run without SVCs during peak load conditions, as shown in Table 4, Table 5, Figure 6 and Figure 7. The simulation results of the power flow and voltage stability analysis of the 60-bus network without FACTs controllers shows that some distribution lines are overloaded, the heavily loaded distribution lines and their percentage loading are; Christ School (115.19\%), Ajowa $(112.4 \%)$, State $(108.01 \%)$, Police Station $(106.69 \%)$, Adebayo (105.21\%) and Orire (101.31\%) as in Table IV.

The curve in Figure 9 is a graphical representation of the responses of the bus voltage magnitudes to the increasing values of active loads. The curve also indicates that the maximum transfer capacity of the distribution network under the initial steady-state stood at $150 \%$ of the total distribution network active load.

2) Simulation with FACTs controllers (SVCS): The voltage profile of the selected network improved considerably can be observed in Figures 6, Table 4, Figure 7, and Table 5 with the incorporation of SVCs. The voltage stability curve (as in Figure 9), obtained after normalizing the network operating parameters, showed that the distribution network transfer capacity increased to $263 \%$ of the total network active load. In order to realize normal line loading of the distribution network, the following requirements were established. Firstly, there is a need to increase the size of the conductor used for the network and normalize various bus voltage magnitudes that have very low values by applying voltage controlling Static Var Compensators.

In order to appreciate the overall effect of FACTs controllers on the distribution networks, it is highly essential to compare the power system's active power loss with and without FACT'S controllers. Figure 10 indicates that the test power network losses stood at 1.079 MW when the network was run without FACT'S controllers and 0.974 MW when run with FACT'S controllers (SVCs). Comparison between the two indicates a $9.73 \%$ reduction in total active power loss when FACT'S controllers (SVCs) were incorporated into the test power networks. It can be therefore deduced that SVC application into the distribution network can greatly reduce active power loss.

\section{CONCLUSION}

This work applies Static Var Compensator (SVC) to AdoEkiti's $11 \mathrm{kV}$ power distribution network, Nigeria. This is to study its effects on active power loss reduction and voltage profile improvement of the network. The distribution network was modeled and simulated in NEPLAN software environment with and without FACT'S controller (SVCs). The simulation results of the power flow and voltage stability analyses of the network without SVCs showed that some distribution lines were overloaded and that the network parameters were not within the statutory tolerable limits. However, with the suitable placement of SVCs, the system bus voltages were enhanced, and the distribution power losses were reduced.

\section{ACKNOWLEDGMENT}

The authors are grateful to appreciate the Benin Electricity Distribution Company (BEDC), Ado-Ekiti, for providing the data.

\section{REFERENCES}

[1] P. K.Olulope, "Optimizing power loss on Nigerian weak transmission line using FACTS devices and Genetic Algorithm," Journal of Electrical and Electronic Engineering, vol. 13, pp. 07-16. June, 2018.

[2] B. Adebanji, G.A. Adepoju, P.K. Olulope, E.T. Fasina and O. Adetan, "Feasibility and optimal design of a hybrid power system for rural electrification for a small village in Nigeria," International Journal of Electrical and Computer Engineering, vol.10, pp.6214-6224, Dec. 2020.

[3] C. I. Anesi, J. K. .Bala and A. O.Ibe, " Impact of network reconfiguration: a case study of Port-Harcourt town $132 / 33 \mathrm{kV}$ subtransmission and its $33 \mathrm{kV}$ injection substation distribution network," European Journal of Electrical and Computer Engineering,vol.1, pp.113, Oct., 2017. 
[4] O.D. Atoki, B. Adebanji, A. Adegbemile, E.T. Fasina and O.D. Akindele, "Sustainable energy growth in Nigeria: the role of gridconnected hybrid power system," International Journal of Scientific and Technology Research, 9 (9), pp. 274-281, June, 2020.

[5] A. Onlam, D. Yodphet, R. Chatthaworn, C. Surawanitkun, A.Siritaratiwat and P. Khunkitti, "Power loss minimization and voltage stability improvement in electrical distribution system via network reconfiguration and distributed generation placement using novel adaptive shuffled frogs leaping algorithm" Energies ,vol.12, pp. 553$559,2019$.

[6] T, Fasina, B. Adebanji, A. Abe, and I. Ismail, "Impact of distributed generation on Nigerian power network," International Journal of Electrical Engineering and Computer Science, 9 (4), pp. 304-3050, March, 2021.

[7] S. W. Mathew, S. Tita, I.A. Adejumobi and A. Elizabeth, "Minimization of active power transmission loss in power systems using static var compensator," International Journal of Applied Engineering Research, vol.13, pp.4951-4959, February 2018.

[8] L. Livdvioavi, "Compensation of reactive of AC catenary system" Procedia Engineering, vol. 18, pp. 185-197, 2017.

[9] S Roy Ghatak and P. Acharjee, "Performance assessment of power system by incorporating distributed generation and static var compensator," International Journal of Emerging technology and Advanced Engineering, vol. 4, pp.1-15, April 2014.

[10] B.Singh and G.Agrawal, "Enhancement of voltage profile by incorporation of SVC in power system networks by using optimal load flow method in MATLAB/Simulink environments," Energy Reports,vol.4, pp.418-434, July 2018.

[11] S.A. Jumaat, I.Musirin and M.M. Baharun, "A voltage improvement of transmission system using static var compensator via Matlab/Simulink," Indonesia Journal of Electrical Engineering and Computer Science, vo.1.6, pp.330-337, May 2017.

[12] V.V.Thishya and K.Balamurigan,"Optimal placement of distributed generation with SVC for power loss reduction in distributed system," ARPN Journal of Engineering and Applied Sciences, vol.12,pp.123134, September, 2017.

[13] K.S.H, Beagam,, R.Jayashree, I.Member, and M.A. Khan, "A new DC power flow Model for Q flow analysis for use in reactive power market," Engineering Science and Technology, an International Journal,vol. 20, pp. 721-729, 2017.

[14] S.Hocine and L.Djamel,"Optimal number and location of UPFC devices to enhance voltage profile and minimizing lossese in electrical power system," International Journal of Electrical and Computer Engineering, vol.9, pp.3981-3992, October 2020.
[15] K.L.KishorPorate, O.L.Thakre and G.L.Bodhe, "Voltage stability enhancement of low voltage radial distribution network using static var compensator. A case study" WSEAS Transaction on Power System,s, vol. 4, Jan., 2009.

[16] B.Pati and S.B. Karajgi, "Optimized placement of multiple FACTS devices using PSO and CSA algorithms, "International Journal of Electrical and Computer Engineering, vol.10., pp.3350-3357, August 2020.

[17] A. N. Abdullah, A.M.Ghadhban, H.S.Hammed and H.I.Hussein, "Enhancement the stability of power system using optimal location of FACTS devices," Indonesia Journal of Electrical Engineering and Computer Science, vol.18, pp.648-655, May 2020.

[18] A.A.Abdullrazzaq, "Improving the power system performance using FACTS devices", Journal of Electrical and Electronic Engineering,,vol.10, pp.41-49, March,2015.

[19] Y. Hasbullah,, B. Mulyadi, Y. Febrian and A.Abdullah, "Optimization placement of static var compensator (SVC) on Electrical Transmission System $150 \mathrm{kV}$ based on smart computation".IOP conf. series: Materials Science and Engineering, 2018, London.

[20] M.Y.Suliman, "Voltage profile enhancement in distribution network using static synchronous compensator STATCOM," International Journal of Electrical and Computer Engineering,vol.10. pp.336703374 , August 2020

[21] J. Chakavorty and M. Gupta, "A new method of load-flow solution of radial distribution networks," International Journal of Electronics and communication Engineering, , vol..5, pp. 9-22, 2012.

[22] M .M. Josephine, N. M.Nndubula and M. V.Chukwuemeka, "Minimizing power losses and voltage enhancing voltage profile of a multi-machine power network using Static Sychronous Compensator (STATCOM) devices, Proceedings of World Congress on Engineering and Computer Science, WCECS, Oct.21-23,2015,USA.

[23] J.Vanishree and U.Ramesh, "Optimization of size and cost of static var compensator using dragonfly algorithmn for voltage profile improvement in power transmission systems", International Journal of Renewabls Energy Research, vol.8, March,2018.

[24] H.Hasbullah,Y.Mulyadi,,W.S.Saputra and N.Muhammed, "Implementation of the SVC in the sub system $150 \mathrm{kV}$ Transmission to improvement Effort Voltage Quality in West Java Area, $4^{\text {th }}$ Annual Applied Science and Engineering Confrence, 2019. USA.

[25] I.A. Samuel, J.Katende, C.OA. Awosope and A.A..Awolewa, "Prediction of voltage collapse in Electrical power system networks using a new voltage stability Index," International Journal of Applied Engineering Research, vol.12, pp.190-199,July,2017. 
APPENDIX A

RECORDED DATA FOR 11 KV ADEBAYO FEEDER AT SUBSTATION FOR PEAK LOAD.

\begin{tabular}{|c|c|c|c|c|c|c|c|c|c|}
\hline $\mathbf{S} / \mathbf{N}$ & $\begin{array}{l}\text { Transformer } \\
\text { Name }\end{array}$ & $\mathbf{S} / \mathbf{S}$ & $\begin{array}{l}\text { Rating } \\
\text { (KVA) }\end{array}$ & $\begin{array}{l}\text { Red Phase / } \\
\text { (Amp) }\end{array}$ & $\begin{array}{l}\text { Yellow phase / } \\
\text { (Amp) }\end{array}$ & $\begin{array}{l}\text { Blue Phase / } \\
\text { (Amp) }\end{array}$ & $\begin{array}{l}\text { Neutral } \\
\text { (Amp) }\end{array}$ & $\begin{array}{l}\text { Load Current / } \\
\text { (Amp) }\end{array}$ & $\begin{array}{l}\% \\
\text { Loading }\end{array}$ \\
\hline 1. & Christ school & & 300 & 222 & 229 & 218 & 69 & 246 & 59 \\
\hline 2. & Ajowa & & 500 & 480 & 295 & 294 & 97 & 389 & 56 \\
\hline 3. & State & & 500 & 234 & 256 & 219 & 23 & 244 & 35 \\
\hline 4. & Adebayo & & 500 & 332 & 326 & 300 & 18 & 325 & 47 \\
\hline 5. & Orire & & 315 & 211 & 217 & 228 & 18 & 225 & 51 \\
\hline 6. & Jimoh aliyu & & 500 & 298 & 288 & 279 & 24 & 296 & 43 \\
\hline 7. & Friendly & & 300 & 234 & 218 & 219 & 16 & 227 & 54 \\
\hline 9. & Olora & & 500 & 623 & 645 & 599 & 23 & 630 & 91 \\
\hline 10. & Ifelere & & 300 & 189 & 199 & 200 & 18 & 202 & 48 \\
\hline 11. & Cele & & 500 & 300 & 385 & 335 & 70 & 363 & 52 \\
\hline 12. & Oriapata & & 500 & 355 & 315 & 325 & 55 & 350 & 50 \\
\hline 13. & Iyalaje & & 500 & 225 & 247 & 305 & 39 & 272 & 39 \\
\hline 14. & Opopogboro & & 500 & 334 & 325 & 313 & 35 & 336 & 48 \\
\hline 15. & Abaibira 1 & & 300 & 145 & 139 & 142 & 9 & 145 & 35 \\
\hline 16. & Abaibira 2 & & 300 & 145 & 134 & 128 & 8 & 138 & 33 \\
\hline 18. & Ifesowapo & & 300 & 290 & 162 & 142 & 31 & 175 & 42 \\
\hline 19. & Aponwe & & 500 & 234 & 214 & 239 & 17 & 235 & 34 \\
\hline 20 & Goshen & & 300 & 190 & 162 & 142 & 31 & 392 & 94 \\
\hline 21. & Olorunsogo & & 300 & 399 & 372 & 369 & 31 & 392 & 94 \\
\hline 22. & Olorunda 1 & & 300 & 234 & 211 & 199 & 46 & 230 & 55 \\
\hline 23. & Olorunda 2 & & 300 & 222 & 198 & 192 & 14 & 209 & 50 \\
\hline 24. & Olart & & 200 & 150 & 120 & 102 & 40 & 137 & 49 \\
\hline 25. & Balemo & & 300 & 234 & 215 & 241 & 23 & 238 & 57 \\
\hline 26. & Bolorunduro & & 500 & 252 & 249 & 311 & 40 & 284 & 41 \\
\hline 27. & Adehun & & 500 & 311 & 276 & 292 & 25 & 301 & 43 \\
\hline 28. & Ileileri & & 300 & 358 & 400 & 350 & 40 & 383 & 92 \\
\hline 29. & Peace 1 & & 500 & 257 & 269 & 301 & 32 & 286 & 41 \\
\hline 30. & Peace 2 & & 300 & 132 & 122 & 143 & 15 & 137 & 33 \\
\hline 31. & Ore ofe & & 300 & 220 & 205 & 103 & 76 & 207 & 48 \\
\hline 32. & Irewumi & & 300 & 125 & 150 & 176 & 30 & 160 & 38 \\
\hline 33. & Ilokun1 & & 300 & 148 & 122 & 156 & 31 & 152 & 37 \\
\hline 34. & Ilokun & & 300 & 159 & 124 & 149 & 34 & 155 & 37 \\
\hline
\end{tabular}

APPENDIX B

RECORDED DATA FOR $11 \mathrm{KV}$ OKESA FEEDER AT Substation FOR PEAK LOAD

\begin{tabular}{|c|c|c|c|c|c|c|c|c|c|}
\hline $\mathbf{S} / \mathbf{N}$ & S/S Name & $\begin{array}{l}\text { Rating } \\
\text { (KVA) }\end{array}$ & $\begin{array}{l}\text { Red Phase / } \\
\text { (Amp) }\end{array}$ & $\begin{array}{l}\text { Yellow phase / } \\
\text { (Amp) }\end{array}$ & $\begin{array}{l}\text { Blue phase / } \\
\text { (Amp) }\end{array}$ & $\begin{array}{l}\text { Neutral } \\
\text { (Amp) }\end{array}$ & I & $\begin{array}{l}\text { Load current / } \\
(\text { Amp) }\end{array}$ & $\begin{array}{l}\text { \% } \\
\text { Loading }\end{array}$ \\
\hline 1. & Police station & 300 & 244 & 254 & 246 & 15 & & 253 & 61 \\
\hline 2. & Palace & 500 & 567 & 589 & 556 & 23 & & 578 & 83 \\
\hline 3. & Old garage & 500 & 456 & 446 & 449 & 18 & & 456 & 66 \\
\hline 4. & Idolofin & 300 & 438 & 409 & 398 & 36 & & 427 & 53 \\
\hline 5. & Oke ese & 300 & 222 & 265 & 228 & 59 & & 258 & 62 \\
\hline 6. & SUBEB & 300 & 160 & 212 & 200 & 85 & & 219 & 53 \\
\hline 7. & Dallimore & 500 & 395 & 348 & 558 & 187 & & 496 & 71 \\
\hline 9. & $\begin{array}{l}\text { Okeila } 3 \text { (rose } \\
\text { bud) }\end{array}$ & 500 & 438 & 382 & 419 & 110 & & 453 & 65 \\
\hline 10. & $\begin{array}{l}\text { Okeila(ibo } \\
\text { church) }\end{array}$ & 300 & 220 & 180 & 226 & 65 & & 230 & 55 \\
\hline 11. & Odo Orobo & 300 & 290 & 233 & 269 & 95 & & 296 & 71 \\
\hline 12. & $\begin{array}{l}\text { Housing } \\
\text { corporation }\end{array}$ & 500 & 400 & 360 & 380 & 90 & & 410 & 59 \\
\hline 13. & Ekiti 1 & 300 & 91 & 161 & 165 & 15 & & 144 & 35 \\
\hline 15. & Fed housing 1 & 300 & 450 & 185 & 248 & 100 & & 328 & 71 \\
\hline 16. & Fed housing 2 & 500 & 530 & 474 & 460 & 108 & & 524 & 75 \\
\hline 17. & Fed housing 3 & 500 & 164 & 226 & 272 & 111 & & 264 & 38 \\
\hline 18. & $\begin{array}{l}\text { Fed housing } \\
\text { phase 2 }\end{array}$ & 300 & 90 & 156 & 151 & 12 & & 136 & 33 \\
\hline 19. & Onala & 300 & 212 & 169 & 218 & 60 & & 220 & 53 \\
\hline 20. & Park view 1 & 315 & 375 & 260 & 205 & 60 & & 300 & 69 \\
\hline 21. & Park view2 & 500 & 425 & 262 & 276 & 193 & & 385 & 55 \\
\hline 22. & Upper land & 300 & 92 & 262 & 176 & 49 & & 193 & 46 \\
\hline 23. & Covenant & 200 & 266 & 83 & 227 & 44 & & 207 & 74 \\
\hline 24. & Shelter view & 500 & 180 & 77 & 251 & 47 & & 185 & 27 \\
\hline 25. & Prison & 300 & 84 & 62 & 83 & 21 & & 83 & 20 \\
\hline
\end{tabular}

